\title{
CHARACTERIZATION, ANTIBACTERIAL AND ANTIOXIDANT ACTIVITY OF MANGOSTEEN (Garcinia mangostana L.) PERICARP NANOSIZED EXTRACT
}

\author{
Purwantiningsih Sugita*, Salsabila Arya, Auliya Ilmiawati and Budi Arifin \\ Department of Chemistry, Faculty of Mathematics and Natural Sciences, Bogor Agricultural \\ University, Dramaga, Bogor, Indonesia-16680 \\ *E-mail : purwantiningsih@apps.ipb.ac.id
}

\begin{abstract}
The difference of crude size was reported to give impact over magosteen pericarp nanosized extract (ME) antibacterial and antioxidant activity. Nano-sized ME $(213,6 \mathrm{~nm})$ showed the best antibacterial activity in inhibiting the growth of bacteria compared to extract from crude with a particle size of 20 mesh and 40 mesh. In the other hand, its antioxidant activity was the lowest. Meanwhile, the chemical compound contained in the ME supposed to support both activities. This research was conducted to characterize the fractions from nano-sized ME based on its antibacterial as well as antioxidant activity. The fractionation of extract provided 6 fractions. Fraction 5 and 6 had the highest antibacterial activity over B. cereus, S. aureus, and S. flexneri and also for antioxidant activity. The result of GC-MS for fraction 5 showed that the fraction contained a high abundance of fatty acid, but fraction 3 was identified to contain 1,3,7trihydroxy-2,8-diisoprenylxanthone and (R)-(-)-mellein.
\end{abstract}

Keywords: antibacterial, antioxidant, mangosteen pericarp nanosized extract, xanthone

@ RASĀYAN. All rights reserved

\section{INTRODUCTION}

Mangosteen pericarp has been used as traditional medicine to heal several diseases such as flu, cystitis, diarrhea, dysentery, eczema, fever, pruritus, gut and skin disease ${ }^{1}$. Extract and the isolated compound from mangosteen pericarp was reported to have varried phamarcologic activities such as antibacterial and antioxidant ${ }^{2}$. The antibacterial agent is a chemical compound that is able to inhibit the growth of bacteria by interfering its metabolism ${ }^{3}$. In the pharmaceutical field, the antibacterial agent is required to prevent or heal infectious disease that might be caused by a pathogen and resistant bacterial ${ }^{4}$. Meanwhile, the antioxidant agent can postpone or inhibit substrate oxidation ${ }^{5}$. Oxidation reaction possibly produces a free radical compound that is able to initiate any other oxidation reaction. It can cause cell damage or worse, death. Therefore, the antioxidant agent is also necessary to stop the intermediate free radical compound to inhibit the other oxidation reaction and prevent the damage ${ }^{6}$.

Ibrahim et al. ${ }^{7}$ reported that ME has activity variation such as antioxidant, anticancer, anti-inflammation, anti-allergic, antibacterial, antifungal, antiparasite, anti-obesity, and has potency as Alzheimer drug. Parhusip et al. ${ }^{8}$ and Putra ${ }^{9}$ reported that mangosteen pericarp ethanol extract can inhibit Staphylococcus aureus, Bacillus cereus, Escherichia coli, Leuconostoc mesenteroides, and Lactobacillus plantarum growth zone. Mangosteen pericarp ethanol extract also had effective concentration value in inhibiting 50\% (IC $\mathrm{I}_{50}$ ) 1,1-diphenyl-2-picrylhydrazyl (DPPH) of $7.48 \mu \mathrm{g} / \mathrm{mL}^{10}$. Siampa ${ }^{11}$ researched the effect of mangosteen pericarp extract sample size to antibacterial and antioxidant activity. The mangosteen pericarp extract was prepared from a sample having a size of $213.6 \mathrm{~nm}, 40 \mathrm{mesh}$, and 20 mesh. The mangosteen pericarp (ME) nanosized extract had a bit higher antibacterial activity average in inhibiting S. aureus, B. Cereus, and Shigella flexineri growth than 40 and 20 mesh extract, but its antioxidant activity in DPPH inhibition was the opposite and the difference was significant enough. The $\mathrm{ME} \mathrm{IC}_{50}$ value was higher $(99.4 \mathrm{ppm})$ than 40 $(60.3 \mathrm{ppm})$ and 20 mesh $(49.4 \mathrm{ppm})$ extract. The phytochemical analysis result from those three extracts did not show any differences. Those three extracts in ethanol extract showed the positive result to flavonoid, tannin and polyphenol, triterpenoid, alkaloid, and saponin compound ${ }^{11}$. The aim of this research was to

Rasayan J. Chem., 10(3), 707-715(2017)

http://dx.doi.org/10.7324/RJC.2017.1031766 
identify a compound having a role as antibacterial and also antioxidant from mangosteen pericarp ethanol extract. The chosen extract used in this research was mangosteen pericarp (ME) nanosized extract.

Putra $^{9}$ identified that compound having a dominant role in antibacterial and antioxidant activity in mangosteen pericarp was secondary metabolites from xanthone group. Govindachari et al. ${ }^{12}$ succeed to isolate xanthone compound from mangosteen pericarp, that is $\alpha$-mangostin, gartanin, and 8-desoxygartanin. Obolskiy et al. ${ }^{2}$ summarized some other xanthone compounds that were isolated from mangosteen pericarp that was $\beta$ - and $\gamma$-mangostin, 1- and 3-isomangostin, mangostinon, mangostanol, mangostanin, garsinon B, garsinon D, garsinon E, 9-hidroxycalabaxanthone, and demethylcalabaxanthone.

\section{EXPERIMENTAL}

Apparatus was used in this research were analytical balance, autoclave, oven blower, distillation apparatus, rotary evaporator, laminar, 90 well microplate, ultraviolet (UV) lamp 254 and $366 \mathrm{~nm}$, vacuum liquid chromatography (VLC), flash column chromatography (FCC), UV-visible (UV-Vis) spectrophotometer UVmini-1240 Shimadzu, GC-MS Waters, and common glassware in laboratory. The materials used were mangosteen pericarp (ME) nanosized extract from previous research by Siampa ${ }^{9}$, dimethyl sulfoxide (DMSO), chloroform p.a., ethanol, methanol, acetone, dichloromethane (DCM), $n$-hexane, ethyl acetate, thin layer chromatography (TLC), silica gel $60 \mathrm{GF}_{254}$ for p-TLC, silica gel $60 \mathrm{H}$ for VLC, silica gel 60 (250 - 400 mesh) for FCC and pre-adsorption, disc paper, ampicillin, nutrient agar (NA), nutrient broth (NB), some bacterial: S. aureus, B. cereus, E. coli, and S. flexneri obtained from IPBCC (Institut Pertanian Bogor Culture Collection), 1,1-diphenyl-2-picrylhydrazyl (DPPH) and ascorbic acid p.a.

\section{Fractionation using VLC ${ }^{13}$ and Identification}

The eluent was chosen from the combination of $n$-hexane:ethyl acetate 9:1 to 1:9. Combination giving the best separation profile would be chosen to be used in fractionation using VLC. As much as $25 \mathrm{~g}$ ME was dissolved in acetone with the addition of $50 \mathrm{~g}$ silica gel 60 for pre-adsorption. The mixture was concentrated using rotary evaporator. The result was placed on $250 \mathrm{~g}$ of silica gel $60 \mathrm{H}$ for VLC that had been packed in VLC column. Then, the extract was eluted using $250 \mathrm{~mL}$ of each chosen eluent. The eluates separation profile was identified using TLC with $n$-hexane:ethyl acetate 8:2 eluent, eluates having similar separation profile were combined into a new fraction. All fractions were tested for antibacterial and antioxidant activity. The ME fractions with highest antibacterial and antioxidant activity were characterized by GCMS. The GC condition: front inlet using split mode, with initial temperature $270{ }^{\circ} \mathrm{C}$, pressure $16.38 \mathrm{psi}$, and using helium (He) eluent. Oven condition that was used is initial temperature $60{ }^{\circ} \mathrm{C}$ and final temperature $50^{\circ} \mathrm{C}$. Flow time 39 minutes. The size of the column used was $60 \mathrm{~m} \times 0.25 \mathrm{~mm} \times 0.25 \mu \mathrm{m}$ with static flow rate, $0.9 \mathrm{~mL} /$ minutes. Ionization at mass spectrometer was done using electron ionization (EI). The mass spectrum that was obtained, would be matched with Wiley $9^{\text {th }}$ library.

\section{Antibacterial assay ${ }^{8}$}

The antibacterial assay used disc diffusion method. Each bacteria ( $S$. aureus, B. cereus, E. coli, and $S$. flexneri) were inoculated into NB media and incubated until its optical density reaches 0.6-0.8. As much as $100 \mu \mathrm{L}$ inoculated media was added into $20 \mathrm{~mL}$ NA media in petry dish. The paper disc was placed on the mixture and inoculated with $10 \mu \mathrm{L}$ fraction with concentration variation of $3.12,6.25,12.5,25$, and $50 \%(\mathrm{~b} / \mathrm{v})$. The dishes were covered and incubated at room temperature for 24 hours. After that, the colorless zone around the disc was measured and inhibition index was calculated using the following equation:

$$
\text { Inhibition Index }=\frac{\text { total inhibition zone }- \text { disc diameter }}{\text { disc diameter }}
$$

\section{Antioxidant assay ${ }^{14,15}$}

The antioxidant assay used DPPH scavenging method. Each fraction was dissolved into ethanol with a concentration of $50 \mathrm{ppm}$ stock solution and was then diluted into $25,12.5,6.25$, and $3.12 \mathrm{ppm}$. As much as 
$500 \mu \mathrm{L}$ fraction solution from each concentration was added to $500 \mu \mathrm{L}$ DPPH (125 $\mu \mathrm{M}$ in ethanol). The mixture was shaken and incubated in dark room at room temperature for 30 minutes. The absorbance was measured at wavelength $517 \mathrm{~nm}$ using UV-Vis spectrophotometer. Ascorbic acid was used as positive control. Antioxidant activity in scavenging DPPH was calculated using the following equation 2 . The relation between concentration and activity concentration was determined, and $\mathrm{IC}_{50}$ was measured using interpolation. Antioxidant activity appears in the value of $\mathrm{IC}_{50}$.

$$
\text { Inhibition }(\%)=\frac{(\mathrm{A}-\mathrm{B})}{\mathrm{A}} \times 100
$$

A: Blank absorbance (ethanol and DPPH)

B: Sample absorbance (fraction and DPPH)

\section{ME fractionation}

\section{RESULTS AND DISCUSSION}

VLC fractionation was aimed to classify compounds based on polarity degree while decreasing compounds amount. This way was the first stage to purify a crude extract in advance. The ME fractionation was started by determining eluent from $n$-hexane: ethyl acetate solvent combination with the ratio of 9:1 to 1:9 through TLC. The solvent combination chosen as eluent was $n$-hexane:ethyl acetate having a ratio of 9:1, 8:2, 7:3, 6:4, and 0:10. The chosen eluent was eluent having the ability to separate a lot of spots with the best separation. The ME fractionation used eluent gradation of $n$-hexane: ethyl acetate by eluting with $250 \mathrm{~mL}$ of following eluents: 9:1 (2 times), 8:2 (4 times), 7:3 (2 times), 6:4 (2 times), and 0:10 (2 times) ratio, respectively. The ME fractionation gave 12 eluates. Every eluates separation pattern was identified by TLC and eluates having similar pattern were collected as one fraction. Its collection gave 6 fractions. Weight and chromatogram of 1 - 6 fraction data were shown in Table-1 and Figure-1 respectively.

Table-1: Fraction weight and yield percentage of ME fractionation result using VLC

\begin{tabular}{c|c|c}
\hline Fraction & Weight $(\mathrm{g})$ & Yield $(\%)$ \\
\hline 1 & 0.2690 & 1,08 \\
\hline 2 & 4.0837 & 16,33 \\
\hline 3 & 5.3195 & 21,28 \\
\hline 4 & 5.2582 & 21,03 \\
\hline 5 & 3.6015 & 14,41 \\
\hline 6 & 5.7700 & 23,08 \\
\hline
\end{tabular}

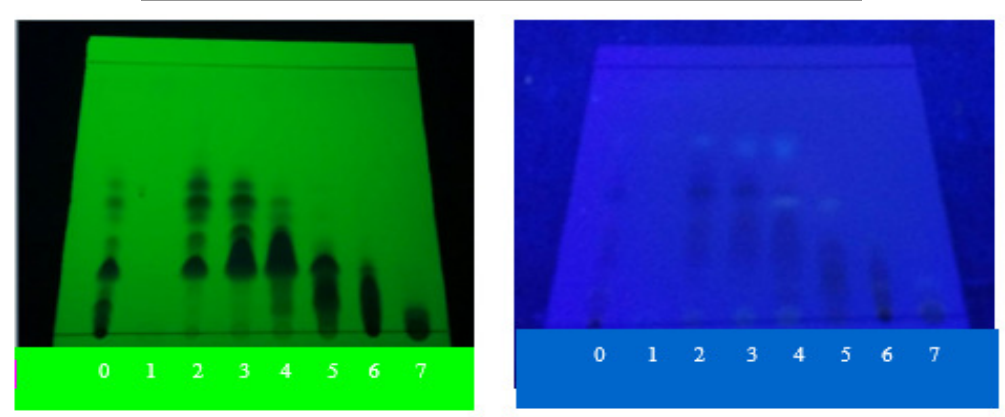

Fig.-1: TLC chromatogram of ME fraction with eluent of $n$-hexane: ethyl acetate (7:3) from (0) ethanol extract, (16) fraction 1 - 6, (7) methanol fraction under (a) UV ( $\left.\lambda_{254 \mathrm{~nm}}\right)$ light and (b) under UV $\left(\lambda_{366 \mathrm{~nm}}\right)$ light

\section{Antibacterial activity of ME fractions}

Every fraction gave different IHD based on colorless zone diameter around the disc. Yet, concentration variation did not influence fraction IHD value. Fraction 1 inhibited $E$. coli growth, but did not inhibit $B$. cereus, S. aureus, and S. flexneri growth. While, fraction 2 until 6 did not inhibit E. coli growth, but inhibit 
B. cereus, S. aureus, and S. flexneri growth (Fig.-2). From the antibacterial activity assay, it showed that fraction 6 gave the stronger inhibition than the other 5 fractions. Fraction 6 hampered the bacterial growth with diameters for $B$. cereus (15 mm with IHD 0.50), S. aureus (13 mm with IHD 0.18), and S. flexneri (15 $\mathrm{mm}$ with IHD 0.50). The IHD value of those six fractions was still lower than ME IHD to B. cereus (1.58), S. aureus (1.72), and E. coli (1.35) at concentration of $50 \%(\mathrm{~b} / \mathrm{v})^{8}$, and also to $S$. flexneri $(0.08)$ at $0.12 \%$ $(\mathrm{b} / \mathrm{v})^{11}$. The high antibacterial activity of the extract can be caused by antagonist effect; effects produced by several fractions were lower than extract before fractionated ${ }^{16}$. The antibacterial activity of this extract also lower than the other plant such as $70 \%$ ethanol extracts from $H$. Suaveoelens inhibiting the bacterial growth with diameters varying from $16 \pm 0$ to $24 \pm 0 \mathrm{~mm}$ and from $15 \pm 0$ to $24 \pm 0 \mathrm{~mm}$ for L. Multiflora. While, the essential oils hampered the bacterial growth with diameters varying from $0 \pm 0$ to $16 \pm 0 \mathrm{~mm}$ for $H$. Suaveoelens and from $20 \pm 0$ to $28 \pm 0 \mathrm{~mm}$ for L. Multiflora ${ }^{17}$.

One thing affecting sample ability in inhibiting bacteria growth was the compound content in that sample and its ability to interact with bacteria membrane. Besides, bacteria type also affected compounds ability to inhibit that bacteria growth. Bacteria can be distinguished into gram positive and gram negative bacteria based on cell membrane structure ${ }^{18}$. The Gram-positive bacterial cell membrane is thicker $(30-80 \mathrm{~nm})$ than gram negative, but it is dominated by peptidoglycan. While gram-negative bacteria has thinner cell membrane layer with more layers amount. It causes gram-negative bacteria to be more resistant to antibacterial and osmotic pressure than gram-positive bacteria. B. cereus and $S$. aureus are belonged to gram-positive bacteria, while $S$. flexneri and E. coli are gram negative bacteria. Even though $S$. flexneri and E. coli are gram negative bacteria, inhibition of both bacteria is different, showed by IHD value difference of every fraction. Siampa ${ }^{11}$ stated that the tougher $E$. coli cell wall structure than other gram-negative bacteria so that the growth inhibition by antibacterial become more difficult.

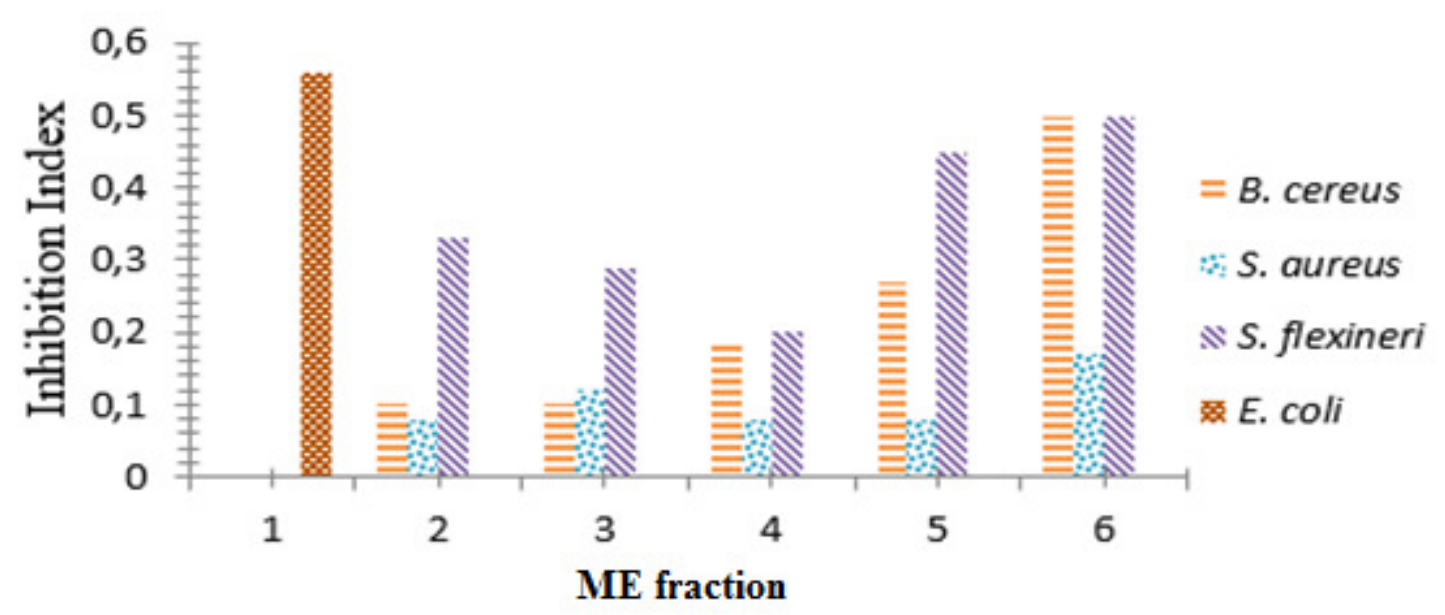

Fig.-2: The ME fraction IHD to several tested bacteria

\section{Antioxidant Activity of ME Fraction}

Fraction 1 until 4 had $\mathrm{IC}_{50}$ value more than 50 ppm, while fraction 5 and 6 has $\mathrm{IC}_{50}$ of $28.19 \mathrm{ppm}$ and 26.86 ppm respectively (Table-2). The $\mathrm{IC}_{50}$ of fraction 5 and 6 were lower than mangosteen pericarp nano extract $\mathrm{IC}_{50}$ that was $99.4 \mathrm{ppm}^{11}$. It showed that fraction antioxidant activity was better than nano ME. Yet, this value was still lower than Tjahjani et al..$^{10}$ Research reported that mangosteen pericarp ethanol extract had effective concentration value in inhibiting $50 \%\left(\mathrm{IC}_{50}\right)$ to $\mathrm{DPPH}$ compound of $7.48 \mu \mathrm{g} / \mathrm{mL}$. The differences of these researches were from sample size and the used solvents. This research used ethanol solvent with $213.6 \mathrm{~nm}$ sample size, while Tjahjani et al. ${ }^{10}$ used methanol solvent with sample size around $40 \mathrm{mesh}$. The phytochemical analysis result from those extracts did not show any differences. Those extracts showed the positive result to flavonoid, tannin and polyphenol, triterpenoid, alkaloid, and saponin compounds. The $\mathrm{IC}_{50}$ is a sample effective concentration in inhibiting $50 \%$ of $\mathrm{DPPH}^{19}$ radical. $\mathrm{IC}_{50}$ value is determined from 
linear regression curve of \% DPPH inhibition with fraction concentration. DPPH is a stable radical compound having purple color if dissolved in ethanol. Compound addition having ability to donate a proton to DPPH is able to change DPPH into non-radical compound, 1,1-diphenyl-2-picrylhydrazyl which is yellow $^{20}$. Purple color intensity decrement indicated the reduced DPPH amount which is able to be determined by UV-Vis spectrophotometer at $517 \mathrm{~nm}^{14}$. Antioxidant activity of fraction 5 and 6 are better than fraction 1 to 4 . Yet, if it is compared to positive control (ascorbic acid), antioxidant activities of both fractions are still low.

Table-2: The $\mathrm{IC}_{50}$ value of ME fraction in inhibiting DPPH radical

\begin{tabular}{c|c}
\hline Sample & $\mathrm{IC}_{50}(\mathrm{ppm})$ \\
\hline Fraction 1 & $>50$ \\
\hline Fraction 2 & $>50$ \\
\hline Fraction 3 & $>50$ \\
\hline Fraction 4 & $>50$ \\
\hline Fraction 5 & 28.19 \\
\hline Fraction 6 & 26.86 \\
\hline Ascorbic acid & 4.45 \\
\hline
\end{tabular}

Many types of research regarding antioxidant were reported from the plants such as Lagenaria siceraria, Bacopa monniera, Jasminum auriculatum, Kalanchoe pinnata and Oxalis corniculata. Durgawale et al. ${ }^{21}$ reported that $O$. corniculata methanol extract contained vitamin E and squalene. These compounds were expected to have an important role in its activity as an antioxidant. Those compounds were also identified through GC-MS in fraction 6 of ME.

\section{Fraction 5 and 3 Identification}

The chosen ME fractions characterized were fraction 5 and 3. Fraction 5 was identified for it had the second highest antibacterial and antioxidant activity after fraction 6 and showed similarity TLC pattern. While fraction 3 was chosen as it has the highest yield among the other 4 fractions and qualitatively showed higher phenolic compound content than the others. The characterization of these fractions used GC-MS.

\section{Fraction 5 Identification}

Fraction 5 chromatogram showed a lot of peaks from retention time of 0 until 20 minutes (Figure 3). At a retention time of 0.00 - 5.59 minutes, there were several peaks of short chain aliphatic hydrocarbon groups such as pentanal $\left(R_{t} 4.85\right.$ minute), hepta-1,3-diene $\left(R_{t} 5.07\right.$ minute $)$, propane $\left(R_{t} 5.29\right.$ minute), and 2pentanone $\left(R_{t} 5.59\right.$ minute). While at a retention time of 6.00 - 13.00 minutes, lactone group peak that is 2furanone ( $R_{t} 7.39$ minute) was identified, the rest peaks belonged to fatty acid groups, that were hexadecanoic acid or palmitic acid $\left(R_{t} 14.69\right.$ minute) and octadecanoic acid or stearic acid $\left(R_{t} 16.147\right.$ minute). Compounds supporting antioxidant activity from fraction 5 did not appear. Perhaps, it was caused by fraction 5 impurities dominated by short chain aliphatic hydrocarbon and several fatty acid compounds. The fatty acid compound was reported to be one of the antibacterial agents that can effectively inhibit the growth of bacterial because its nonpolar side which can interact with cell membrane that contains phospholipid layer ${ }^{22}$. Interactions of fatty acid with the cell membrane of bacteria can cause the formation of pores on the bacterial cell membrane. This is one of antibacterial agent mechanism in damaging bacterial's cell ${ }^{23}$.

\section{Fraction 3}

Fraction 3 had the fourth highest antibacterial and antioxidant activity after fraction 6 and 5. Fraction 3 was chosen to be characterized for its weight was higher than fraction 2 having the $3^{\text {rd }}$ highest antibacterial and antioxidant activity. A lot of peaks were identified in fraction 3 chromatogram from retention time of 0 to 55 minute (Fig.-4). Based on retention time, compounds in fraction 3 were classified into short chain aliphatic hydrocarbon group at a retention time of $0.00-6.13$ minute such as cyclopentanol $\left(R_{t} 5.18\right.$ minute $)$, 
RASĀYAN J. Chem.

Vol. 10 | No. 3 |707 - 715 | July - September | 2017

2-pentanone $\left(R_{t} 5.53\right.$ minute), and ethanol $\left(R_{t} 5.97\right.$ minute). At $R t 15.37$ minute, Isopropyl palmitate, a fatty acid compound was also identified, while at a retention time of 12.00 to 47.13 minute, phenolic group compounds, that are (R)-(-)-Melein and 1,3,7-Trihydroxy-2,4-diisoprenylxanthone (Figure 5) were identified.

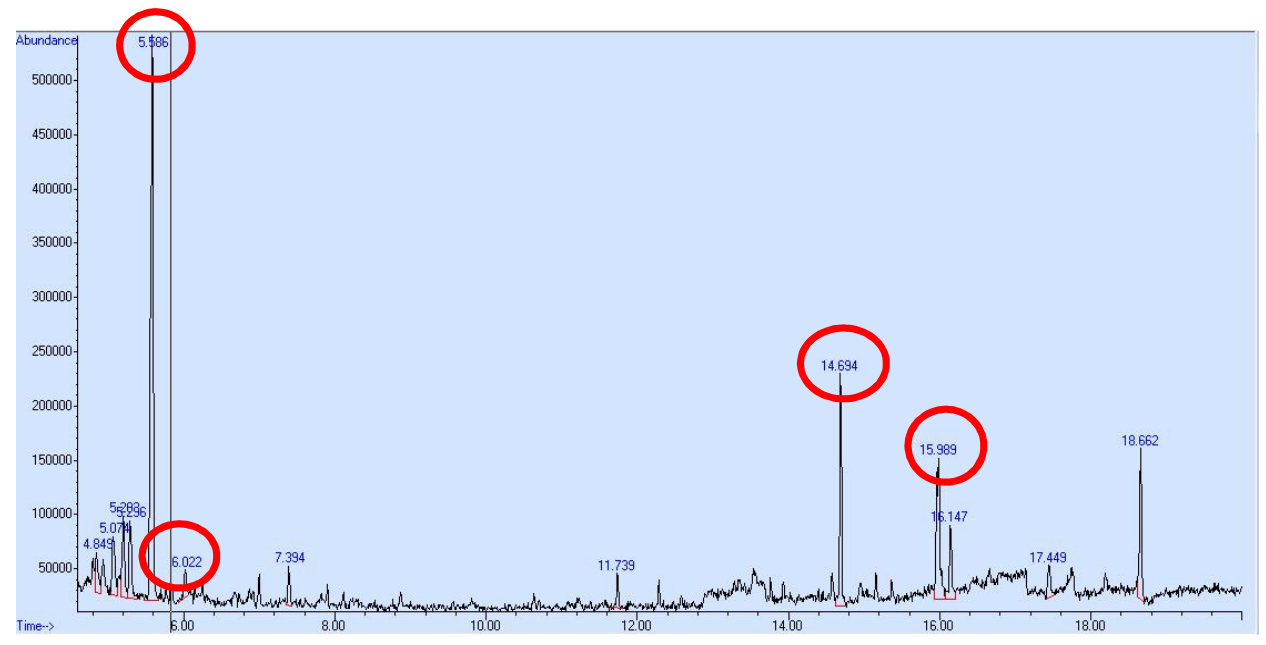

Fig.-3: The fraction 5 of ME chromatogram

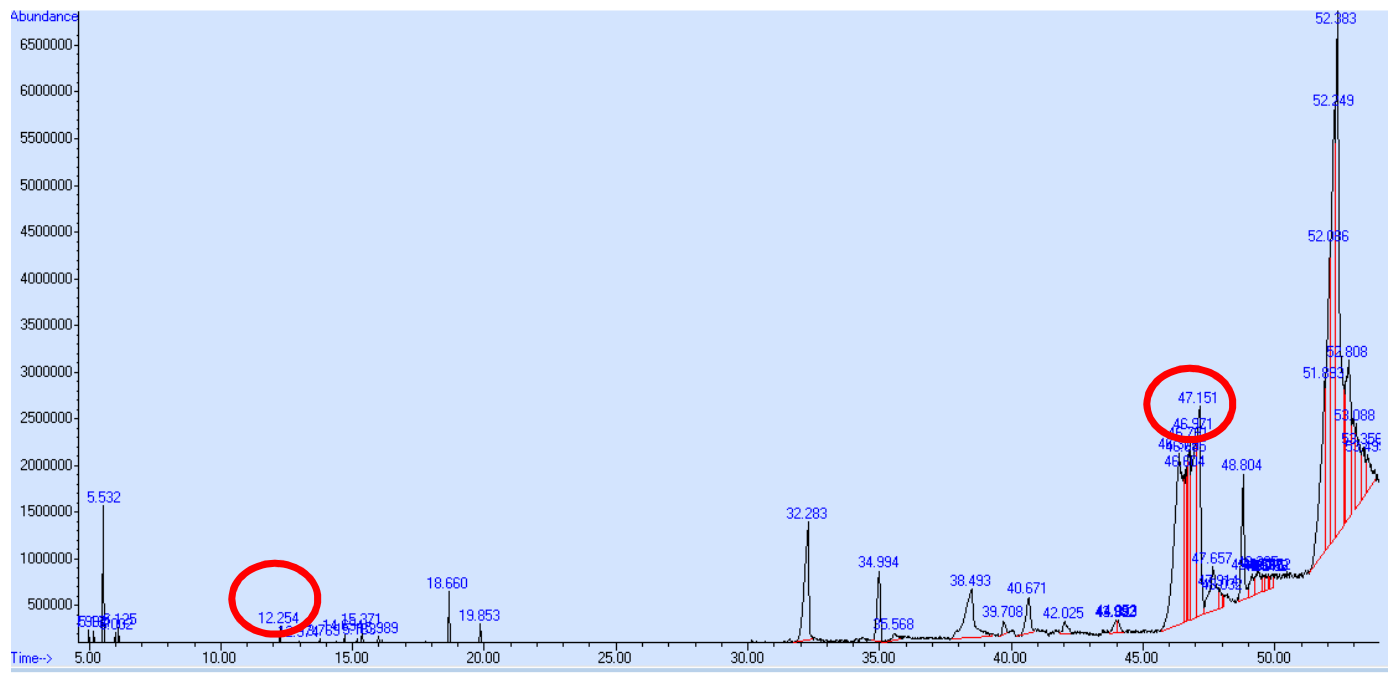

Fig.-4: Fraction 3 of ME chromatogram

(R)-(-)-Melein (Fig.-5a) was identified at $R_{t} 12.25$ minute. This compound belongs to phenolic compound, dihydroisocoumarin derivative ${ }^{24}$. While 1,3,7-trihydroxy-2,4-diisoprenylxanthone (Fig.-5b) was identified at 46.43 minutes. It is phenolic compound from xanthone group which is typical in mangosteen pericarp ${ }^{2}$. The advanced study of a peak having $R_{t} 46.43$ minute by using Wiley $9^{\text {th }}$ database showed that $1,3,7$ trihydroxy-2,4-diisoprenylxanthone was a compound with a molecular weight of 380 and had $\mathrm{C}_{23} \mathrm{H}_{24} \mathrm{O}_{5}$ molecular formula. Mass spectrum of that compound showed similarity to a database that was characterizing fragment appearance at $\mathrm{m} / \mathrm{z} 325$ and 269 whether in fraction 3 spectrum or that standard compound spectrum (Fig.-6). The ion at $\mathrm{m} / z 325$ was reduced as $\left[\mathrm{C}_{19} \mathrm{H}_{17} \mathrm{O}_{5}\right]^{+\cdot}$ releasing $\left[\mathrm{C}_{4} \mathrm{H}_{7}\right]^{+\cdot}$. While ion at $\mathrm{m} / z 269$ was reduced as $\left[\mathrm{C}_{17} \mathrm{H}_{18} \mathrm{O}_{3}\right]^{+\cdot}$ releasing $\left[\mathrm{C}_{6} \mathrm{H}_{6} \mathrm{O}_{2}\right]^{+\cdot}$ (Fig.-7).

Characterization result was conducted by compound abundance approach which can be detected by GCMS based on Wiley $9^{\text {th }}$ database. The advance purification is required to prove the actual structure in order 
to determine the actual compound having antioxidant and antibacterial activity. The advance purification such chromatotron is required so the fraction in a small amount can be separated well. Results from this research support empirical information stating that mangosteen pericarp extract has potential as antibacterial and antioxidant.

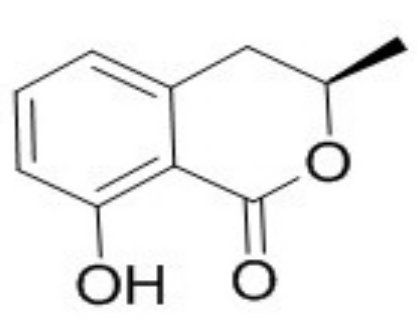

(a)

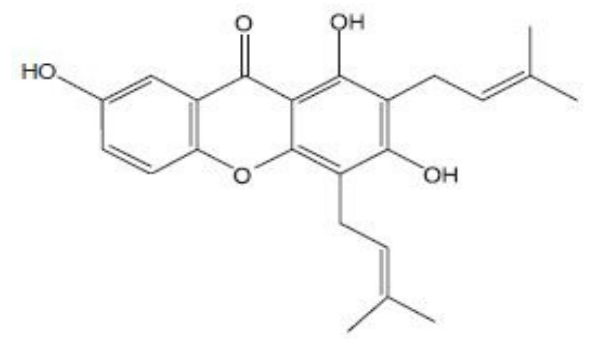

(b)

Fig.-5: Structure of (a) (R)-(-) Melein and (b) 1,3,7-trihydroxy-2,4-diisoprenylxanthone

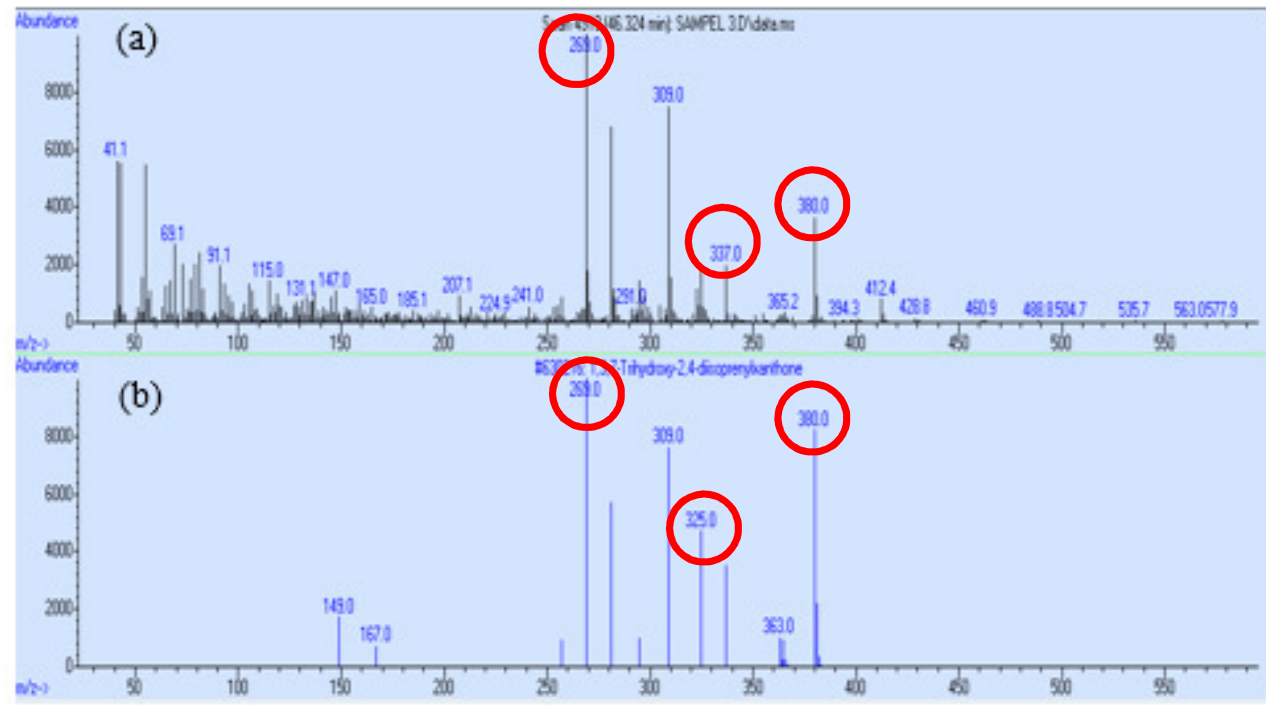

Fig.-6: (a) Mass spectrum of compound having $R_{t} 46.43$ minute and (b) reference mass spectrum of 1,3,7trihydroxy-2.4-diisoprenylxanthone

CONCLUSION

The fraction 5 of ME has antibacterial and antioxidant, even though from GC-MS characterization result showed chromatogram with peaks dominated by fatty acid group compounds, while the phenolic derivative compound was identified in fraction 3. Phenolic compounds identified are dihydroxyisocoumarin group, that is (R)-(-)-mellein and xanthone, that is 1,3,7-trihydroxy-2,8-diisoprenylxanthone.

\section{ACKNOWLEDGEMENT}

The author expresses deepest appreciation to Direktorat Jenderal Pendidikan Tinggi Kementerian Pendidikan dan Kebudayaan No. 083/SP2H/PL/Dit.Litabmas/II/2015, tanggal 5 Februari 2015 who funded this research through BPPTN Bogor Agriculture University research program 2015 on behalf of Prof. Dr. Purwantiningsih Sugita, MS. 
RASĀYAN J. Chem.

Vol. 10 | No. 3 |707 - 715 | July - September | 2017
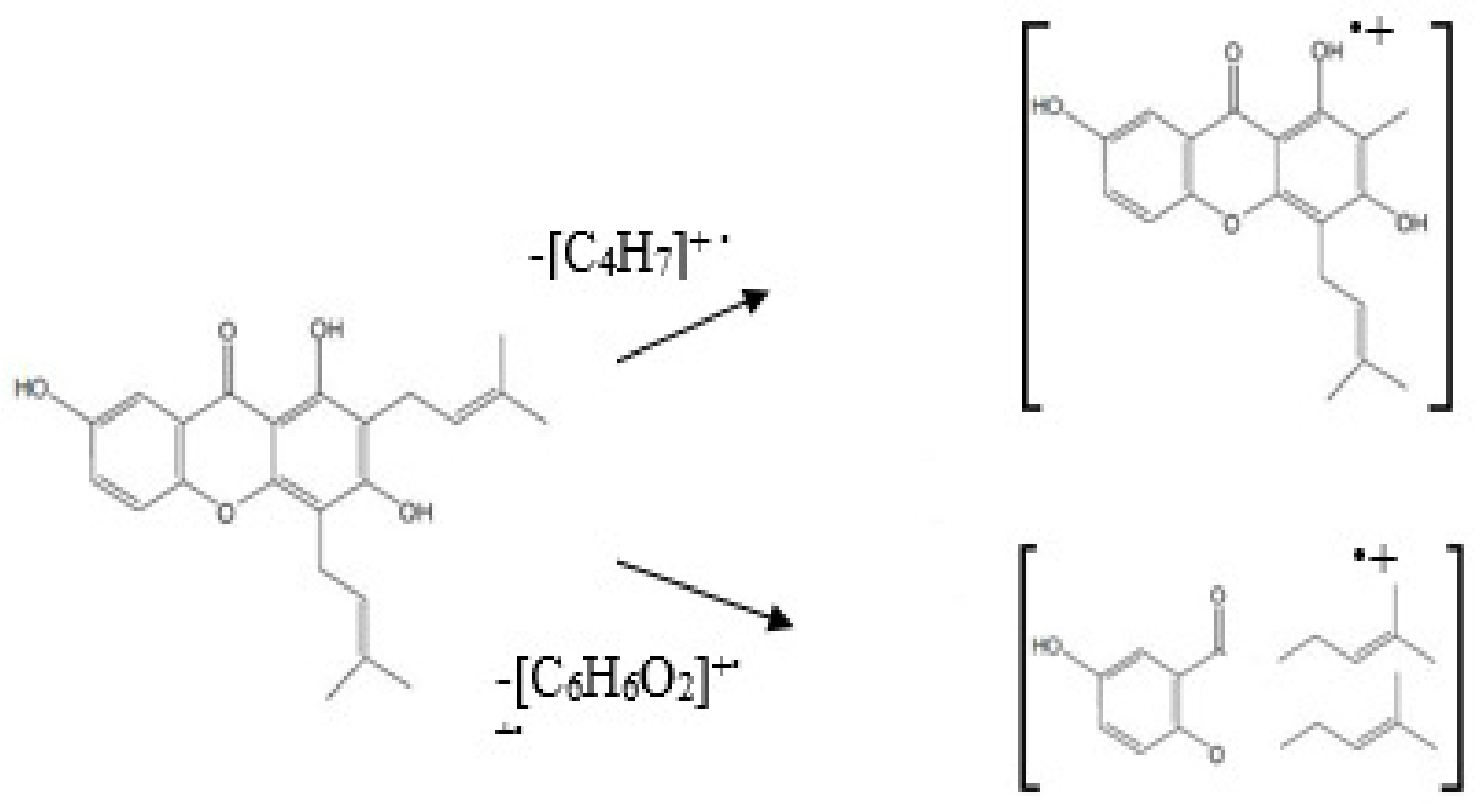

Fig.-7: Fragmentation of 1,3,7-trihydroxy-2,4-diisoprenylxanthone

\section{REFERENCES}

1. Y. Akao, Y. Nakagawa, M. Iinuma, and Y. Nozawa, Int. J. Mol. Sci., 9, 355(2008)

2. D. Obolskiy, I. Pischel, N. Siriwatanametanon, and M. Heinrich, Phytother. Res., 23, 1047(2009)

3. G. Shaik, N. Sujatha, and S.K. Mehar, J. App. Pharm. Sci., 41, 135(2014)

4. J. Berdy, J. Antibiotics, 65, 385(2012)

5. B. Halliwell and J.M.C. Gutteridge, Biol. Med., 18(1),125(1995)

6. Y. Shebis, D. Iluz, Y.K. Tahan, Z. Dubinsky, and Y. Yehoshua. Food and Nutrition Sciences, 4, 643(2013)

7. M.Y. Ibrahim, N.M. Hashim, A.A. Mariod, S. Mohan, M.A. Abdulla, S.I. Abdelwahab, and I.A. Arbab, Arabian J. of Chemistry, 1(2014), http://dx.doi.org/10.1016/j.arabjc.2014.02.011

8. A.J.N. Parhusip, R. Handayani, and Vilona, Jurnal Ilmu dan Teknologi Pangan, 6(2), 25(2008)

9. I.N.K. Putra, J. Teknologi dan Industri Pangan, 21(1), 1(2010)

10. S. Tjahjani, W. Widowati, K. Khiong, A. Suhendra, and R. Tjokropranoto, Procedia Chemistry, 13, 198(2014)

11. S.R.H. Siampa, Master thesis, Post Graduate School of Bogor Agriculture University, Bogor, Indonesia (2016)

12. T. Govindachari, P. Kalyanaraman, N. Muthukumaraswamy, and B.R. Pai, Ind. J. Chem., 27(16), 3919(1971)

13. N.M. Targett, J.P. Kilcoyne, and B. Green, J. Org. Chem., 44(26), 4962(1979)

14. S.J. Leu, Y.P. Lin, and R.D. Lin, Biol. Pharmaceut. Bull., 29(4), 740(2006)

15. R.C. Aranda, L.A.P. Lopez, J.L. Arroyo, B.A.A. Garza, N.W. Torres. Antimicrobial and antioxidant activities of plants from northeast of mexico. Evidence-based complementary and alternative medicine:1-6. doi:10.1093/ecam/nep127. (2011)

16. E. Surahman, E. Mandalas, and E.I. Kardinah, Jurnal Farmasi,, 5(1), 21(2008)

17. K.R.C. Goly, Y. Soro, A. Dadie, A.B.B. Kassi. and D. J. E. Marcellin, Rasayan J. Chem., 8(4),396 (2015)

18. M. Dworkin, S. Falkow, E. Rosenberg, K.H. Schleifer, and E. Stackebrandt. The Prokaryotes: A Handbook on the Biology of Bacteria, Springer, New York. (2006)

19. W. Elfalleh, H. Hannachi, N. Tlili, Y. Yahia, N. Nasri, and A. Ferchichi, J. Med. Plant Res., 6(20), 4724(2012) 
RASĀYAN J. Chem.

Vol. 10 | No. 3 |707 - 715 | July - September | 2017

20. P. Molyneux, J. Sci. Techno.l, 26(2), 211(2004)

21. P.P. Durgawale, A.S. Hendre and R.S. Phatak, Rasayan J. Chem ., 8(3),271(2015)

22. Asriani, B.S. Laksmi, S. Yasni, and I. Sudirman, J. Teknologi dan Industri Pangan, 18(2), 127 (2007)

23. J.B. Parsons, J. Yaoi, M.W. Frank, P. Jackson, and C.O. Rock, J. Bacteriol., 194 (19), 5294(2012)

24. Z. Feng, V.N. Nenkep, K. Yun, D. Zhang, H.D. Choi, J.S. Kang, and B.W. Son, J. Microbiol. Biotechnol., 20(6), 985(2010)

[RJC-1766/2017] 